\title{
MEMBANGUN KEPEMIMPINAN BERBASIS NILAI-NILAI PANCASILA DALAM PERSPEKTIF MASYARAKAT MULTIKULTURAL
}

\author{
Dodik Kariadi ${ }^{1}$ dan Wasis Suprapto ${ }^{2}$ \\ STKIP Singkawang ${ }^{1}$ \\ Email:dodik_kariadi@yahoo.com'; wasissoeprapto@gmail.com²; \\ Naskah diterima: 18/08/2017 revisi: 25/09/2017 disetujui: 24/10/2017
}

\begin{abstract}
Abstrak
Pemimpin organisasi di Indonesia apapun jenisnya harus dilandasi pada nilai-nilai pancasila sebagai landasan falsafah negera. Tujuan dari penulisan ini adalah untuk mengkaji kepemimpinan berdasarkan nilai-nilai luhur pancasila. Metode yang digunakan dalam penulisan ini adalah studi literatur dengan menganalisis dan menggali data dari berbagai sumber relevan. Nilai pancasila jika dikaitkan dengan organisasi harus didasarkan pada (1) nilai dasar, (2) nilai instrumental, dan (3) nilai praktis. Nilai kepemimpinan juga dapat dilakukan pada lembaga dengan mengembangkan nilai (1) transendensi, (2) humanisasi, (3) kebhinekaan, liberasi, dan (5) keadilan. Kelima pilar nilai pancasila tersebut sejatinya dapat menjadi ruh kepemimipinan yang ditampilkan oleh ketua suatu organisasi dalam memimpin.
\end{abstract}

Kata Kunci: Kepemimpinan, Nilai, Multikultural

\section{BUILDING LEADERSHIP BASED ON PANCASILA VALUES IN A MULTICULTURAL COMMUNITY PERSPECTIVE}

Abstract

Any organization leader in Indonesia of any kind should be based on the values of Pancasila as the foundation of the state philosophy. The purpose of this paper is to examine the leadership based on the noble values of Pancasila. The method used in this paper is the study of literature by analyzing and exploring data from various relevant sources. The value of Pancasila if associated with the organization should be based on (1) the basic value, (2) the instrumental value, and (3) the practical value. The value of leadership can also be done on institutions by developing values (1) transcendence, (2) humanization, (3) diversity, liberation, and (5) justice. The five pillars of Pancasila value can actually become the spirit of leadership that is displayed by the chairman of an organization in the lead.

Keywords: Leadership, Value, Multicultural 


\section{PENDAHULUAN}

Pemimpin yang baik adalah pemimpin yang mampu membangun nilai dan norma bersama kelompok yang dia ayomi dimana orang tersebut berkiprah. Nilai penting ada dalam organisasi sebagai acuan bergeraknya seluruh anggota organisasi kearah pencapaian tujuan bersama dari kelompok tersebut.Dalam suatu Kehidupan di masyarakat selalu muncul seorang pemimpin yang dapat mempengaruhi dan mengarahkan perilaku anggota masyarakat ke arah tujuan tertentu (Wahyudi, 2009). Begitu juga dalam lembaga pendidikan selalu dimunculkan seorang pemimpin yang mampu menggerakkan dan mempengaruhi anggotanya, sekaligus sebagai wakil sekaligus panutan dari anggota tersebut dalam hubungannya dengan pihak luar. Dalam usaha untuk memenuhi harapan, pemimpin menggunakan segala kemampuan yang dimilikinya dan memanfaatkan lingkungan serta potensi yang dimiliki dalam organisasi yang dikelola.

Guna memanjukan

memberdayakan anggota maka seorang pemimpin dalam organisasi harus mendasarkan setiap langkahnya pada nilai serta memahami nilai tersebut secara mendalam. Pemahaman tentang nilai tersebut sangat ditentukan oleh bagaimana pemahaman seorang pemimpin tentang nilai itu terbentuk. Ada nilai yang diinginkan dan sangat diinginkan, dan dalam konteks interaksi dalam kelompok ada nilai yang tidak diinginkan karena tidak berkesesuaian dengan apa yang diharakan. Jadi nilai adalah prinsip dasar yang menjadi pegangan setiap orang dalam hidup dan kehidupannya. Proses pembentukan nilai terjadi ketika interaksi antar manusia terjadi, dimana nilai dalam fungsi sehari-hari menjadi pedoman orang berperilaku dan mengarahkan orang untuk berperilaku sesuai dengan ketentuan yang berlaku. Ketika organisasi tanpa bentukan nilai yang menjadi pedoman bagi anggotanya, maka organisasi tidak akan dapat menjalankan fungsinya sesuai dengan apa yang diharpkan, dan akan kehilangan makna atas apa yang menjadi target utamanya.

Dengan demikian menurut asumsi sementara penulis, konsepsi kepemimpinan berbasis nilai pancasila dalam masyarakat multikultural inilah yang kemudian melatar belakangi penulis untuk mengkaji lebih dalam dan berupaya mengungkapkan makna dibalik itu. Atas dasar hal tersebut penulis anggap penting untuk dapat dijadikan contoh atau model kepemimpinan berbasis nilai pancasila pada segala lini masyarakat karena pada dasarnya masyarakat Indonesia merupakan masyarakat yang perlu penanganan serta pembinaan yang ekstra akan tetapi harus tetap dilandasi pada nilai Pancasila. Selain hal tersebut, sebagai masayarakat yang taat terhadap idiologi dan dasar Negara maka nilai-nilai pancasila harus tetap menjadi acuan dalam menjalankan roda organisasi yang ada di Indonesia.

\section{METODE}

\section{Jenis Penelitian}

Artikel ini didasarkan pada studi kepustakaan atau library research. Library research adalah rentetan aktivitas penelitian yang berkaitan dengan bagaimana cara dan metode yang tepat dalam pengumpulan data kajian, menapsirkan dan mendaftar serta menyiapkan komposisi kajian yang dibahas. Hal ini merupakan suatu penelitian yang memanfaatkan sumber perpustakaan untuk memperoleh data penelitiannya (Mustika Zed, 2004). Dalam artikel ini, penulis menggunakan metode penelitian deskriptif kualitatif-kritis. Penelitian deskriptif-kritis dengan lebih menekankan pada kekuatan analisis sumber-sumber dan data-data yang bergantung pada teori-teori dan naskahnaskah yang ada untuk diterjemahkan berlandaskan tulisan-tulisan yang mengarah kepada diskusi utama. Landasan-landasan di atas didapat dari karya yang ditulis oleh intelektual dan ahli yang berkompeten.

\section{Waktu dan Tempat Penelitian}




\section{Citizenship Jurnal Pancasila dan Kewarganegaraan Vol 3 No 1 Maret 2017, hal 86-96 Avaliable online at : http://e-journal.unipma.ac.id/index.php/Citizenship ISSN: 2302-433X (print) 2579-5740 (online)}

Proses penyusunan artikel ini dimulai dengan menyusun anggapan dasar dan aturan berpikir yang akan digunakan dalam artikel. Anggapan dan aturan berpikir tersebut selanjutnya dilaksanakan secara teratur dalam pengelompokan dan pengolahan data untuk memberikan penjelasan dan uraian berupa pengumpulan dan penyusunan data, serta analisis dan penafsiran data tersebut untuk menjelaskan fenomena dengan aturan berpikir ilmiah yang diterapkan secarateratur tanpa menggunakan model normatif dengan mengadakan pengelompokan, penilaian standar norma, hubungan dan kedudukan suatu parameter dengan parameter lain.

\section{Target/Subjek Penelitian}

Target/subjek penelitian ini merupakan data-data yang berupa nota, transkrip, buku, dan sebagainya yang mempunyai keterkaitan dengan kepemimpinan, pancasila dan multikultural.

\section{Prosedur}

Penelitian ini dimulai dengan mengumpulkan data, dan setelah semua data terkumpul maka data tersebut dianalisis untuk mendapatkan konklusi, dimana teknik analisis yang digunakan adalah analisis deskriptif. Selain itu dilakukan juga analisis isi, dimana analisis isi dengan membandingkan antara satu kajian dengan kajian yang lain dalam bidang yang sama dengan artikel ini, baik berdasarkan perbedaan waktu penulisannya maupun mengenai kemampuan kajian-kajian tersebut dalam mencapai sasaran sebagai bahan yang disajikan sekelompok masyarakat yang menjadi objek dari kajian tersebut.

Data, Intrumen, dan Teknik Pengumpulan Data

Data yang diperlukan dalam penulisan artikel ini bersifat kualitatif tekstual dengan menggunakan pijakan terhadap statement dan proporsi-proporsi ilmiah yang dikemukakan oleh para pakar yang erat kaitannya dengan pembahasan. Sumber data dalam artikel ini menggunakan personal dokumen, yaitu dokumen pribadi yang berupa bahan-bahan tempat orang yang mengucapkan dengan kata-kata mereka sendiri (Furqan, 1992). Personal dokumen sebagai sumber dasar atau data primernya, dalam hal ini adalah buku-buku yang berkaitan dengan artikel ini.

Teknik pengumpulan data yang digunakan yakni teknik dokumentasi, mendata wacana dari buku-buku, makalah atau artikel, majalah, jurnal, koran, internet, ataupun keterangan lainnya yang berhubungan dengan artikel untuk mencari data-data yang berupa nota, transkrip, buku, dan sebagainya yang mempunyai keterkaitan dengan artikel ini.

\section{Teknik Analisis Data}

Hal ini dilakukan dengan analisis wacana (discourse analysis) supaya tidak tumpang tindih dalam melakukan analisa. Setelah semua data terkumpul maka data tersebut dianalisis untuk mendapatkan konklusi, dimana teknik analisis yang digunakan adalah analisis deskriptif. Selain itu dilakukan juga analisis isi, dimana analisis isi dengan membandingkan antara satu kajian dengan kajian yang lain dalam bidang yang sama dengan artikel ini, baik berdasarkan perbedaan waktu penulisannya maupun mengenai kemampuan kajiankajian tersebut dalam mencapai sasaran sebagai bahan yang disajikan sekelompok masyarakat yang menjadi objek dari kajian tersebut.

\section{HASIL DAN PEMBAHASAN Kepemimpinan}

Kepemimpinan dalam kamus besar bahasa Indonesia (2008), dijelaskan berasala dari kata pemimpin sering disebut penghulu, pemuka, pelopor, pembina, panutan, pembimbing, pengurus, penggerak, ketua, kepala, penuntun, raja, tua-tua, dan sebagainya. Sedangkan istilah memimpin digunakan dalam konteks hasil penggunaan peran seseorang berkaitan dengan kemampuannya mempengaruhi orang lain dengan berbagai cara. Istilah pemimpin, kepemimpinan, dan memimpin pada 
mulanya berasal dari kata dasar yang sama yakni kata pimpin. Dengan demikian kepemimpinan disini secara umum diadopsi dari kata pempin yang memilki makna utama sebagai yang terdepan dalam membawa sekelompok orang atau masyarakat dalam mencapai tujuannya.

Wahjosumidjo (1999) menyatakan bahwa seorang pemimpin memiliki kecerdasan, pertanggung jawaban, sehat dan memiliki sifat sifat antara lain Dewasa, keleluasaan hubungan sosial, motivasi diri dan dorongan prestasi serta sikap hubungan kerja kemanusiaan. Sebaliknya dalam realitas sosial modern, juga dikenal pemimpin karismatik, terutama dalam lingkungan sosial dan politik. Kemudian Edwin B (2000) menyatakan bahwa pemimpin kharismatik mempunyai kesetiaan, tanggung jawab dan dukungan dari pengikutnya. Fungsi pemimpin lebih banyak memberikan konsultasi, bimbingan, motivasi dan memberikan nasihat dalam rangka mencapai tujuan. Menurut Siswanto Sastrohadiwiryo (2003) banyak faktor yang dapat mempengaruhi kinerja pegawai antara lain pendidikan dan pelatihan, disiplin kerja, kompensasi, iklim organisasi, sistem jenjang karier, motivasi, dan kepemimpinan.

George R. Terry (Miftah Thoha, 2010) mengartikan bahwa Kepemimpinan adalah aktivitas untuk mempengaruhi orang-orang supaya diarahkan mencapai tujuan organisasi. Kepemimpinan meliputi proses mempengaruhi dalam menentukan tujuan organisasi, memotivasi perilaku pengikut untuk mencapai tujuan, mempengaruhi untuk memperbaiki kelompok dan budayanya. Sejalan dengan itu, A. Dale Timple (2000) mengartikan Kepemimpinan adalah proses pengaruh sosial dimana manajer mencari keikutsertaan sukarela dari bawahan dalam usaha mencapai tujuan organisasi. Dengan kepemimpinan yang dilakukan seorang pemimpin juga menggambarkan arah dan tujuan yang akan dicapai dari sebuah organisasi. Sehingga dapat dikatakan kepemimpinan sangat berpengaruh bagi nama besar organisasi. Kemudian Sudarwan Danim (2004) menjelaskan bahwa kepemimpinan adalah setiap perbuatan yang dilakukan oleh individu atau kelompok untuk mengkoordinasi dan memberi arah kepada individu atau kelompok yang tergabung di dalam wadah tertentu untuk mencapai tujuan yang telah ditetapkan sebelumnya.

Martinis Yamin dan Maisah (2010) kepemimpinan adalah suatu proses mempengaruhi yang dilakukan oleh seseorang dalam mengelola anggota kelompoknya untuk mencapai tujuan organisasi. Kepemimpinan merupakan bentuk strategi atau teori memimpin yang tentunya dilakukan oleh orang yang biasa kita sebut sebagai pemimpin. Pemimpin adalah seseorang dengan wewenang kepemimpinannya mengarahkan bawahannya untuk mengerjakan sebagian dari pekerjaannya dalam mencapai tujuan.

Dari pendapat di atas dapat disimpulkan kepemimpinan merupakan cara seorang pemimpin dalam mempengaruhi bawahan dengan karakteristik tertentu sehingga dapat mencapai tujuan yang diinginkan. Faktor keberhasilan seorang pemimpin salah satunya tergantung dengan teknik kepemimpinan yang dilakukan dalam menciptakan situasi sehingga menyebabkan orang yang dipimpinnya timbul kesadarannya untuk melaksanakan apa yang dikehendaki. Dengan kata lain, efektif atau tidaknya seorang pemimpin tergantung dari bagaimana kemampuannya dalam mengelola dan menerapkan pola kepemimpinannya sesuai dengan situasi dan kondisi organisasi tersebut.

Edwin A. Locke (1991) menyatakan terdapat empat kunci untuk memimpin dengan sukses yang ditunjukkan dalam model kepemimpinan. Empat kunci ini adalah: 1. Alasan dan sifat-sifat pemimpin/Motives dan traits. 2 . Pengetahuan, keahlian, dan kemampuan /Knowledge, Skills, and Ability/KSAs 3. Visi 4. Implementasi dari visi. 


\section{Citizenship Jurnal Pancasila dan Kewarganegaraan Vol 3 No 1 Maret 2017, hal 86-96 Avaliable online at : http://e-journal.unipma.ac.id/index.php/Citizenship ISSN: 2302-433X (print) 2579-5740 (online)}

Beberapa orang berpendapat bahwa seorang pemimpin yang efektif dapat menyebabkan pengikutnya secara tidak sadar dengan kemampuan dirinya berkorban demi organisasi (Bass, 1985 dalam Locke, et al, 1991). Definisi yang lebih baik dari pemimpin efektif mengerjakan dengan menghargai bawahannya dengan kemampuan diri mereka dalam mencapai visi yang telah diformulasikan dan bekerja untuk mewujudkannya. Terdapat beberapa hal bagaimana pemimpin memotivasi bawahan yaitu: 1. Meyakinkan bawahan bahwa visi organisasi (dan peran bawahan dalam hal ini) penting dan dapat dicapai. 2. Menantang bawahan dengan tujuan, proyek, tugas, dan tanggung jawab dengan memperhitungkan perasaan diri bawahan akan sukses, prestasi, dan kecakapan. 3. Memberikan penghargaan kepada bawahan yang berkinerja baik dengan penghargaan, uang, dan promosi.

Fungsi kunci seorang pemimpin adalah membangun visi organisasi dan mengkomunikasikan kepada bawahan. Terdapat beberapa karakteristik dari pernyataan visi yaitu: ringkas, jelas, abstrak, menantang, orientasi ke depan, stabilitas, dan disenangi. Kebijakan dan prosedur yang spesifik diperlukan untuk mengimplementasikan visi ini terdiri dari enam kategori yaitu: 1. Menstrukturisasi 2. Menyeleksi, melatih, dan menyesuaikan diri bawahan 3. Memotivasi bawahan 4. Mengelola informasi 5. Membangun tim 6. Perubahan kemajuan.

Masalah kepemimpinan selalu memberi kan kesan menarik dari waktu ke waktu. Kepemimpinan ini memainkan peran penting dalam berbagai aktivitas organisasi. Dalam kepemimpinan ini, seorang pemimpin harus memberikan pengarahanpengarahan terhadap usaha-usaha semua bawahan dalam mencapai tujuan organisasi. Higgs (2003) mengungkapkan bahwa terdapat empat hal yang sering menjadi bahasan dalam berbagai literatur terkait dengan peran pemimpin yaitu: 1 . Perubahan dalam nilai-nilai sosial 2. Perubahan fokus investor 3. Tantangan dalam melaksanakan perubahan organisasi 4 . Kesadaran terhadap dampak stress bagi karyawan.

Terdapat banyak teori maupun pendekatan dalam kepemimpinan. Beberapa ahli membedakan kepemimpinan menjadi dua yaitu: kepemimpinan transformational dan transaksional. Pada dasarnya kepemimpinan transaksional dan transformasional merupakan dasar dari sebuah gaya kepemimpinan. Gaya kepemimpinan tersebut pada beberapa dekade terakhir muncul sebagai fenomena dan dirasakan memiliki dampak positif terhadap beberapa aspek yang dapat meningkatkan efektivitas organisasi.

Kepemimpinan transaksional adalah hubungan antara pemimpin dan bawahan yang berlandaskan pada adanya pertukaran atau adanya tawar menawar antara pemimpin dan bawahannya. Menurut Burns (1978) dalam Muchji dan Priyono (2004), kepemimpinan transaksional adalah motivasi pengikut terutama melalui dasar pertukaran reward. Reward tersebut dapat berupa bonus atau peningkatan gaji atau penghargaan lainnya. Dalam kepemimpinan transformasional pertukaran yang terjadi antara bawahan dan pimpinan tidak sekedar pertukaran seperti yang terjadi pada kepemimpinan transaksional. Kepemimpinan transformasional juga melibatkan pengembangan hubungan yang lebih dekat antara pemimpin dengan pengikut.

Bass dan Avolio (1990) dalam Muchji dan Priyono (2004), ada 4 unsur yang mendasari kepemimpinan transformasional yaitu: a) Charisma: kharismatik pada pemimpin transformasional didapatkan dari pandangan pengikut, sehingga seorang pemimpin yang berkharisma akan mempunyai banyak pengaruh dan dapat menggerakkan serta dapat mengilhami bawahannya dengan suatu visi yang dapat diselesaikan melalui usaha keras. b) Inspiration: pemimpin yang inspirasional 
dapat mengartikulasikan tujuan bersama serta dapat menentukan suatu pengertian mengenai apa yang dirasa penting serta apa yang dirasakan benar, sehingga pemimpin dapat mempertinggi arti serta meningkatkan harapan yang positif mengenai apa yang perlu dilakukan. c) Intellectual stimulation: para pemimpin membantu bawahannya untuk dapat memikirkan mengenai masalahmasalah lama dengan cara baru. d) Individualized consideration: seorang pemimpin harus mampu untuk memperlakukan bawahannya secara berbeda-beda namun adil, yaitu mampu memperhatikan satu persatu bawahannya dan tidak hanya mengenali kebutuhannya serta meningkatkan perspektif bawahan, namun juga memberikan prasarana dalam rangka pencapaian tujuan secara efektif serta memberi pekerjaan yang memberikan tantangan yang lebih.

\section{Nilai-Nilai Pancasila}

Berbicara tentang nilai-nilai Pancasila tidak bisa terlepas dari pengertian dasar Pancasila. Pancasila merupakan kumpulan lima nilai unidimensional yang dijadikan acuan tingkah laku bangsa Indonesia. Kelima nilai yang terkandung dalam Pancasila adalah ketuhanan pada sila pertama, kemanusiaan pada sila kedua, patriotism pada sila ketiga, demokrasi pada sila keempat, dan keadilan sosial pada sila kelima. Sejalan dengan itu Daroeso (1989) menjelaskan bahwa apabila kita merujuk pada sejarah jauh sebelum Soekarno menggali nilai Pancasila yang dikenal saat ini, konsep Pancasila sudah lebih dahulu terdokumentasidi kerajaan Majapahit yang tetuang dalam kitab gubahan Mpu Sutasoma milik $\mathrm{Mpu}$ Tantular. Kitab tersebut merumuskan lima karma, yaitu yang pertamatidak boleh melakukan kekerasan, keduatidak boleh mencuri, ketiga tidak boleh berjiwa dengki, dan keempat tidak boleh berbohong, dan tidak boleh mabuk minuman keras.
Sila pertama dalam Pancasila mencakup nilai ketuhanan. Dimana sila pertama ini terkait dengan karakter transedensi yang merupakan kekuatan yang menempa hubungan individu dengan semesta yang lebih luas serta menyediakan makna. Dalam transendensi terdapat apresiasi terhadap keindahan dan keunggulan, rasa syukur (gratitude), harapan, humor, dan religiusitas; hal-hal yang merupakan bagian dari sila pertama. Poin ketuhanan ini mengisyaratkan harus dijunjungnya toleransi antarumat beragama. Keberadaan berbagai penganut agama berbeda di Indonesia bukan tidak mungkin dapat menimbulkan adanya konflik. Oleh sebab itu, nilai ketuhanan dianggap penting untuk dijadikan landasan kehidupan bernegara, yaitu sebagai salah satu poin yang tercantum dalam Pancasila (Meinarno, 2012).

Nilai mengenai kemanusiaan diangkat menjadi poin yang tercakup pada sila kedua Pancasila. Nilai kemanusiaan yang ini lebih menekankan pada perlakuan seorang individu terhadap individu atau masyarakat lainnya. Berdasarkan sila ini, setiap orang harus menghormati dan menghargai orang lain sebagai sesama manusia. Oleh karena itu, dituntut pula adanya sikap adil dalam memperlakukan orang lain, tanpa melihat suku, ras, ataupun perbedaan lainnya yang dimiliki orang lain tersebut. Poin mengenai persatuan dicantumkan pada sila ketiga Pancasila. Persatuan sebagai nilai ini berusaha dicapai dengan dijadikannya Bahasa Indonesia sebagai bahasa resmi nasional. Penggunaan Bahasa Indonesia di berbagai kegiatan, misalnya dalam kegiatan akademis, perdagangan, pergaulan, diharapkan dapat menjadi pemersatu masyarakat di Indonesia meskipun mereka berasal dari suku atau agama yang berbeda. Dengan berbahasa Indonesia yang baik dan benar, akan terpupuk rasa persatuan bagi masyarakat Indonesia karena adanya kebakuan yang dipahami secara bersamasama (Meinarno, 2012). 
Pada sila keempat, tercantum nilai mengenai tanggung jawab dan harmoni. Nilai ini merupakan nilai yang kental bagi Indonesia yang menganut budaya demokrasi. Nilai sila keempat lah yang mendasari warga negara untuk dapat memahami keputusan yang diambil pemimpin (yang awalnya dipilih secara bersama pula) untuk kemaslahatan bersama. Nilai keempat ini juga berhubungan dengan keutamaan keadilan dan transedensi. Sila terakhir Pancasila mengenai keadilan sosial yang harus diwujudkan di Indonesia. Tampakya hal-hal di dalam nilai kelima ini erat dengan bagaimana rasa adil tidak semata untuk diri, tapi untuk masyarakat tempat individu berada. Pembuatan kategori ini merupakan dampak logis dari tidak terbentuknya satu konstruk Pancasila sebagaimana yang diperkirakan sebelumnya (Suwartono \& Meinarno, 2011; 2012). Justru hasil ini seakan menegaskan bahwa ide dasar yang diajukan oleh Soekarno tepat adanya yakni kumpulan nilai. Hal ini agak berseberangan dengan ide dari Soeharto yang lebih menekankan bahwa Pancasila adalah satu kesatuan utuh yang masingmasing sila saling menjiwai. Dengan cara pandang itu maka Pancasila sering disebut sebagai satu konstruk.

Implikasi lainnya adalah bahwa Pancasila merupakan sistem nilai.Susunan nilai terdiri dari gagasan-gagasan yang tertanam dalam otak sebagian besar masyarakat, mengenai hal-hal yang harus mereka anggap amat bernilai dalam hidup. Dengan demikian suatu sistem nilai biasanya berfungsi sebagai pedoman tertinggi bagi kelakuan manusia (Koentjaraningrat, 1974). Ide ini sejalan dengan pernyataan Soekarno saat rapat pada tanggal 1 Juni 1945 yang menggagas tentang dasar Negara Indonesia.

Pancasila yang berisi seperangkat nilai-nilai dasar ideal, merupakan komitmen kebangsaan, identitas bangsa dan menjadi dasar pembangunan karakter Keindonesiaan. Mendasarkan pada perspektif teori fungsionalisme struktural, sebuah negara bangsa yang majemuk seperti Indonesia membutuhkan nilai bersama yang dapat dijadikan nilai pengikat integrasi (integrative value), titik temu (common denominator), jati diri bangsa (national identity) dan sekaligus nilai yang dianggap baik untuk diwujudkan atau ideal value (Winarno Narmoatmojo, 2010).

Sebagai ideologi nasional, nilai-nilai dasar Pancasila menjadi cita-cita masyarakat Indonesia yang sekaligus menunjukan karakter bangsa yang hendak dibangun. Karakter, identitas atau jati diri sebuah bangsa bukanlah sesuatu yang telah jadi. Karakter adalah hasil konstruksi dan produk dari pembudayaan melalui pendidikan.Pancasila mendasari dan menjiwai semua proses penyelenggaraan negara dalamberbagai bidang serta menjadi rujukan bagi seluruh rakyat Indonesia dalam bersikap dan bertindak dalam kehidupannya sehari-hari. Pancasila memberikan suatu arah dan kriteria yang jelas mengenailayak atau tidaknya suatu sikap dan tindakan yang dilakukan oleh setiap warga negara Indonesia dalam kehidupan bermasyarakat, berbangsa dan bernegara.

Moerdiono (1999) menjelaskan bahwa terdapat tiga tataran nilai dalam ideologi Pancasila yaitu nilai dasar, nilai instrumental, dan nilai praksis.Dimana ketiga nilai ini menjadi suatu bagian yang menjadi penentu sukses dan tidaknya implementasi dari pelaksanaan nilai-nilai yang tercantuk dalam idiologi pancasila. Ketiga nilai ini terjabar dalam uraian yang antara lain:

Pertama Nilai dasar, yaitu suatu nilai yang bersifat amat abstrak dan tetap, yang terlepas dari pengaruh perubahan waktu. Nilai dasar merupakan prinsip, yang bersifat amat abstrak, bersifat amat umum, tidak terikat oleh waktu dan tempat, dengan kandungan kebenaran yang bagaikan aksioma. Dari segi kandungan nilainya, maka nilai dasar berkenaan dengan eksistensi sesuatu, yang mencakup cita-cita, 
tujuan, tatanan dasar dan ciri khasnya. Nilai dasar Pancasila ditetapkan oleh para pendiri negara. Nilai dasar Pancasila tumbuh baik dari sejarah perjuangan bangsa Indonesia melawan penjajahan yang telah menyengsarakan rakyat, maupun dari citacita yang ditanamkan dalam agama dan tradisi tentang suatu masyarakat yang adil dan makmur berdasarkan kebersamaan, persatuan dan kesatuan seluruh warga masyarakat

Kedua Nilai instrumental, yaitu suatu nilai yang bersifat kontekstual. Nilai instrumental merupakan penjabaran dari nilai dasar tersebut, yang merupakan arahan kinerjanya untuk kurun waktu tertentu dan untuk kondisi tertentu. Nilai instrumental ini dapat dan bahkan harus disesuaikan dengan tuntutan zaman. Namun nilai instrumental haruslah mengacu pada nilai dasar yang dijabarkannya. Penjabaran itu bisa dilakukan secara kreatif dan dinamik dalam bentuk-bentuk baru untuk mewujudkan semangatyang sama, dalam batas-batas yang dimungkinkan oleh nilai dasar itu. Dari kandungan nilainya, maka nilai instrumental merupakan kebijaksanaan, strategi, organisasi, sistem, rencana, program, bahkan juga proyek-proyek yang menindaklanjuti nilai dasar tersebut. Lembaga negara yang berwenang menyusun nilai instrumental ini adalah MPR, Presiden, dan DPR.

Ketiga Nilai praksis, yaitu nilai yang terkandung dalam kenyataan sehari-hari, berupa cara bagaimana rakyat melaksanakan (mengaktualisasikan) nilai Pancasila. Nilai praksis terdapat pada demikian banyak wujud penerapan nilai-nilai Pancasila, baik secara tertulis maupun tidak tertulis, baik oleh cabang eksekutif, legislatif, maupun yudikatif, oleh organisasi kekuatan sosial politik, oleh organisasi kemasyarakatan, oleh badan-badan ekonomi, oleh pimpinan kemasyarakatan, bahkan oleh warganegara secara perseorangan.

Jika mengacu pada lima sila Pancasila, maka menurut Gunawan (2012). Pancasila sebagai inti karakter bangsa Indonesia, mengandung lima pilar karakter, yakni: pertama transendensi, menyadari bahwa manusia merupakan ciptaan Tuhan Yang Maha Esa. Dari-Nya akan memunculkan penghambaan semata-mata pada Tuhan. Kesadaran ini juga berarti memahami keberadaan diri dan alam sekitar sehingga mampu memakmurkannya. Dimana manusia menggunakan pemikiran mendalam untuk mempelajari sifat Tuhan yang dianggap begitu jauh, berjarak dan mustahil dipahami manusia; keduahumanisasi, dimana hal ini merupakan proses menjadikan manusia sebagai manusia sesuai dengan kodratnya sebagai manusia.setiap manusia pada hakikatnya setara di hadapan Tuhan kecuali ketakwaan dan ilmu yang membedakannya, manusia diciptakan sebagai subyek yang memiliki potensi; ketiga kebinekaan, kesadaran akan ada sekian banyak perbedaan di dunia, akan tetapi, mampu mengambil kesamaan untuk menumbuhkan kekuatan; keempat liberasi, pembebasan atas penindasan sesama manusia, oleh karena itu tidak dibenarkan adanya penjajahan manusia oleh manusia; dan kelima keadilan, merupakan kunci kesejahteraan, adil tidak berarti sama, tetapi proporsional.

Berdasarkan beberapa pemaparan di atas maka dapat ditarik kesimpulan bahwa Pancasila memiliki nilai-nilai yang dapat dijadikan sebagai pedoman oleh seorang yang menjadi pimpinan organisasi. Apabila pancasila dijadikan sebagai landasan idiologi maka harus memuat tiga macam nilai utama yaitu nilai dasar, instrumental dan praksis. Kemudian apabila pancasila dijadikan sebagai basis utama dalam menjalankan organisasi maka transendensi, humanisasi, kebinekaan dan keadilan harus menjadi pegangan ketua dalam organisasi tersebut.

\section{Masyarakat Multikultural}

Kelompok masyarakat Indonesia merupakan masyarakat dengan tingkat keanekaragaman serta perbedaan yang 
sangat kompleks atau majemuk. Kelompok masyarakat dengan bebagai keanekaragaman dan kemajemukan tersebut dikenal dengan istilah masyarakat multikultural atau Multicultural society. Jika kita mengenal masyarakat sebagai sekelompok masyarakat yang telah cukup lama hidup dan bekerja sama sehinga mereka mampu mengorganisasikan dirinya dan berpikir tentang dirinya sebagai satu kesatuan sosial dengan batas-batas tertentu, maka konsep masyarakat tersebut jika digabungkan dengan multicultural memiliki makna yang sangat luas dan diperlukan pemahaman yang mendalam untuk dapat mengerti apa sebenarnya masyarakat multicultural itu.

Acuan utama bagi terwujudnya masyarakat Indonesia yang multikultural adalah multikulturalisme, yaitu sebuah ideologi yang mengakui dan mengagungkan perbedaan dalam kesederajatan baik secara individual maupun secara kebudayaan (Fay 1996, Jary dan Jary 1991, Watson 2000). Dalam model multikulturalisme ini, sebuah masyarakat (termasuk juga masyarakat bangsa seperti Indonesia) dilihat sebagai mempunyai sebuah kebudayaan yang berlaku umum dalam masyarakat tersebut yang coraknya seperti sebuah mosaik. Di dalam mosaik tercakup semua kebudayaan dari masyarakat-masyarakat yang lebih kecil yang membentuk terwujudnya masyarakat yang lebih besar, yang mempunyai kebudayaan yang seperti sebuah mosaik tersebut (Reed, ed. 1997). Model multikulturalisme ini sebenarnya telah digunakan sebagai acuan oleh para pendiri bangsa Indonesia dalam mendesain apa yang dinamakan sebagai kebudayaan bangsa, sebagaimana yang terungkap dalam penjelasan Pasal 32 UUD 1945, yang berbunyi: "kebudayaan bangsa (Indonesia) adalah puncak-puncak kebudayaan di daerah".

Multikulturalisme bukan hanya sebuah wacana tetapi sebuah ideologi yang harus diperjuangkan, karena dibutuhkan sebagai landasan bagi tegaknya demokrasi, HAM, dan kesejahteraan hidup masyarakatnya. Multikulturalisme bukan sebuah ideologi yang berdiri sendiri terpisah dari ideologiideologi lannya, dan multikulturalisme membutuhkan seperangkat konsep-konsep yang merupakan bangunan konsep-konsep untuk dijadikan acuan bagi memahaminya dan mengembang-luaskannya dalam kehidupan bermasyarakat. Untuk dapat memahami multikulturalisme diperlukan landasan pengetahuan yang berupa bangunan konsep-konsep yang relevan dengan dan mendukung keberadaan serta berfungsinya multikulturalisme dalam kehidupan manusia. Bangunan konsepkonsep ini harus dikomunikasikan diantara para ahli yang mempunyai perhatian ilmiah yang sama tentang multikultutralisme sehinga terdapat kesamaan pemahaman dan saling mendukung dalam memperjuangkan ideologi ini. Berbagai konsep yang relevan dengan multikulturalisme antara lain adalah, demokrasi, keadilan dan hukum, nilai-nilai budaya dan etos, kebersamaan dalam perbedaan yang sederajat, sukubangsa, kesukubangsaan, kebudayaan sukubangsa, keyakinan keagamaan, ungkapan-ungkapan budaya, domain privat dan publik, HAM, hak budaya komuniti, dan konsepkonsep lainnya yang relevan (Fay 1996, Rex 1985, Suparlan 2002).

Suparlan (2005) menyatakan bahwa konsep masyarakat multikultural (multicultural society) perlu dibedakan dengan konsep masyarakat majemuk (plural society) yang menunjukkan keanekaragaman suku bangsa dan kebudayaan suku bangsa, multikulturalisme dikembangkan dari konsep pluralisme budayaatau masayarakat yang memiliki budaya beranekaragam dengan menekankan pada kesederajatan kebudayaan yang ada dalam suatu masyarakat. Sejalan dengan itu (Azra, 2006) menjelaskan bahwa multikulturalisme ini mengusung semangat untuk hidup berdampingan secara damai (peaceful coexistence) dalam perbedaan 
budaya yang ada baik secara individual maupun secara kelompok dan masyarakat.

Selanjutnya Koentjaraningrat (1982) juga menjelaskan bahwa konsep pluralisme yang menekankan keanekaragaman suku bangsa dan kebudayaannya, sehingga setiap kebudayaan dipandang sebagai entitas yang destruktif, maka multikulturalisme lebih menekankan hubungn antar-kebudayaan dengan pengertian bahwa keberadaan suatu kebudayaan atau peradaban harus mempertimbangkan keberadaan kebudayaan atau peradaban lainnya. Dari sini lahir gagasan atau konsep kesetaraan, toleransi, saling menghargai, dan sebagainya. Membangun masyarakat multikulturalisme Indonesia berarti membangun suatu ideologi yang menempatkan kesetaraan dalam perbedaan pada posisi sentral.

Namun, sebagaimana halnya setiap konsep dalam ilmu pengetahuan, khususnya ilmu sosial, konsep multikulturalisme tak luput dari perbedaan pengertian. Mengikuti Bikhu Parekh (2001) istilah multikulturalisme mengandung tiga komponen, yakni, pertama, konsep ini terkait dengan kebudayaan; kedua, konsep ini merujuk kepada pluralitas kebudayaan; dan ketiga, konsep ini mengandung cara tertentu untuk merespons pluralitas itu. Oleh sebab itu multikulturalisme bukanlah doktrin politik pragmatik melainkan sebagai cara pandang atau semacam ideologi dalam kehidupan manusia. Oleh karena hampir semua negara di dunia tersusun dari anekaragam kebudayaan artinya perbedaan menjadi asasnya dan gerakan manusia dari satu tempat ke tempat lain di muka bumi semakin intensif, maka multikulturalisme sebagai ideologi itu harus diterjemahkan ke dalam kebijakan multicultural sebagai politik pengelolaan perbedaan kebudayaan warga negara dengan mengutamakan kesetaraan dan saling menghargai. Tetapi, yang masih menjadi pertanyaan besar, model kebijakan multikultural seperti apa yang dapat dikembangkan oleh suatu negara-bangsa seperti Indonesia.
Kehidupan masyarakat multikultural Indonesia yang telah dicita-citakan oleh para pendiri bangsa atau the founding fatheradalah masyarakat multikultural indonesia yang menjadikan nilai-nilai Pancasila sebagai acuan yang mengatur kehidupannya warga negara. Sebagai dasar kehidupan bernegara, Pancasila memiliki nilai-nilai yang menjadi pedoman kehidupan berbangsa dan bernegara bagi setiap warga negara.

\section{SIMPULAN DAN SARAN}

\section{Simpulan}

Kepemimpinan berbasis nilai-nilai Pancasila merupakan upaya membumikan Pancasila di pada semua ormas dan lembaga. Kepemimpinan yang menginternalisasikan nilai-nilai Pancasila mutlak harus diimplementasikan, di tengah terbukanya tatanan global. Ormas dan lembaga sebagai tempat berkumpulnya orang mengemban tugas untuk mengukuhkan, memformulasikan, menyatukan, dan menciptakan masyarakat yangberasaskan Pancasila disetiap sendisendi kehidupan. Pimpinan ormas dan lembaga merupakan keyperson terwujudnya lingkungan dan budaya organisasi yang Pancasilais. Pimpinan dalam seluruh kegiatan memiliki kewajiban menanamkan nilai-nilai Pancasila kepada anggotanya, dengan memasukkan kandungan nilai-nilai Pancasila dalam setiap kegiatan dan program organisasi. Kalau mengacu pada sila-sila Pancasila, maka diperoleh beberapa hal penting tekait dengan pilar-pilar nilai kepemimpinan yang harus dilaksanakan oleh seorang pemimpin dalam setiap lembaga, antara lain, pertama transendensi, kedua humanisasi, ketiga kebhinekaan, keempat liberasi, dan kelimakeadilan. Lima pilar nilai kepemimpinan Pancasila tersebut menjadi ruh kepemimpinanyang ditampilkan oleh pimpinan dalam memimpin ormas atau lembaganya. Jika pimpinan menampilkan sifat lima pilar kepemimpinan Pancasila dan juga 
menampilkan keteladanan yang menjiwai Pancasila, maka anggota atau pegawai pun akan meneladani pimpinan. Sehingga ormas atau lembaga menjadi wahana yang efektif dalam merevitalisasi dan membumikan Pancasila. Ormas dan lembaga menjadi model penerapan kepemimpinan berbasis nilai-nilai Pancasila.

\section{DAFTAR PUSTAKA}

Azra,A. (2006). Pancasila dan identitas nasional Indonesia: perspektif multikulturalisme. Dalam restorasi Pancasila: Mendamaikan Politk identitas dan modenitas. Bogor. Brighten Press

Arif, M. (2014). Model kerukunan sosial pada masyarakat multikultural cina benteng (kajian historis dan sosiologis). Sosio Didaktika: Vol. 1 , No. 1

Faisal, S. (1992).Format-format penelitian sosial (dasar-dasar dan aplikasi) Jakarta: Rajawali.

Arief F. (1992). Pengantar Metode Penelitian Kualitatif. Surabaya: Usaha Nasional.

Danim, S. (2004). Motivasi Kepemimpinan dan Efektivitas Kelompok. Penerbit Rineka Cipta.

Daroeso, Bambang. (1989). Dasar dan Konsep Pendidikan Moral Pancasila. Semarang: Aneka Ilmu.

Edwin B. Flippo. (2000). Terjemahan Marwansyah dan Mukaram, Manajemen Sumber Daya Manusia. Penerbit Erlangga.

Gunawan, Heri. (2012). Pendidikan Karakter Konsep dan Implementasi. Bandung: Alfabeta.

Koentjaraningrat. (1974). Kebudayaan Mentalitas dan Pembangunan, Gramedia Pustaka Utama, Jakarta.

Koentjaraningrat. (1982). Manusia dan Kebudayaan Indonesia. Jakarta: Djambatan.
Meinarno, E. A. Dkk. (2011). Manusia Dalam Kebudayaan Masyarakat. Jakarta: Salemba Humanika.

Miftah T. 2010. Kepemimpinan dan Manejemen. Rajawali Press: Jakarta.

Moerdiono. (1999). Pancasila Sebagai Ideologi, Jakarta: BP-7 Pusat

Mustika Zed. (2004). Metode Penelitian Kepustakaan. Jakarta: Yayasan Obor Nasional

Siswanto S. (2003). Manjemen tenaga kerja, edisi 2. Jakarta: PT. Bumi Aksara

Soliha, Euis dan Hersugondo. 2008. Kepemimpinan yang Efektif dan Perubahan Organisasi. Fokus Ekonomi (FE), Vol.7, No.2 Hal. 83-93

Suparlan, Pi, (1999), "Kemajemukan Amerika: Dari Monokulturalisme ke Multikulturalisme". Jurnal Studi Amerika, vol.5 Agustus, hal. 35-42.

Timple, A.D. (2000). Seri Manajemen Sumber Daya Manusia Kepemimpinan .Jakarta: PT Elex Media Komputindo.

Wahjosumidjo. (1999). Kepemimpinan Kepala Sekolah, Jakarta: Raja Grafindo Persada.

Wahyudi. (2009). Kepemimpinan Kepala Sekolah dalam Organisasi Pembelajaran (Learning Organization). Bandung: Alfabeta.

Winarno Narmoatmojo. (2010). Implementasi Pancasila Melalui Pendidikan Kewarganegaraan (Civic Education). Yogyakarta: Ombak

Yamin, Martinis dan Maisah. (2010). Standarisasi Kinerja Guru. Jakarta: Persada Press.

Departemen Pendidikan Nasional. (2008). Kamus Besar Bahasa Indonesia Pusat Bahasa. Jakarta: PT Gramedia Pustaka Utama 